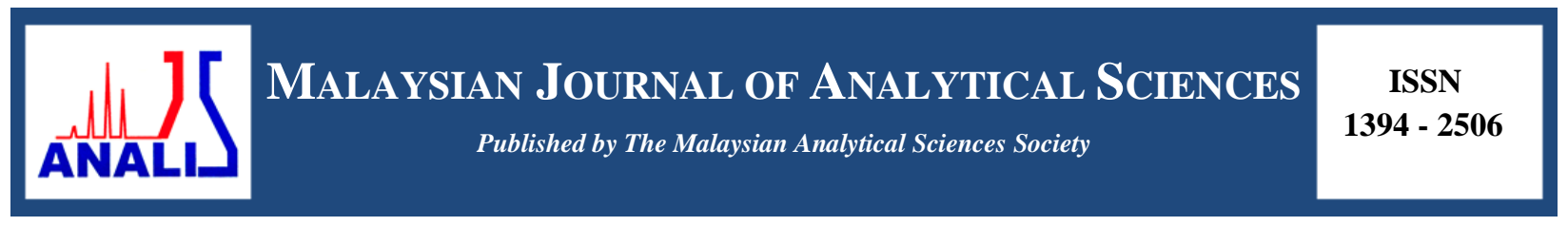

\title{
ESTERIFICATION OF ACETIC ACID AND BENZYL ALCOHOL OVER ZEOLITE HX PRODUCED FROM BANGKA BELITUNG KAOLIN
}

\section{(Pengesteran Asid Asetik dan Benzil Alkohol ke atas Zeolit HX Dihasilkan daripada Kaolin Bangka Belitung)}

\author{
Vita Nur Iftitahiyah ${ }^{1}$, Didik Prasetyoko ${ }^{1} *$ Hartati $^{2}$, Yatim Lailun Ni’mah ${ }^{1}$, Hasliza Bahruji ${ }^{3}$, Hadi Nur ${ }^{4}$ \\ ${ }^{I}$ Department of Chemistry, Faculty of Science, \\ Institut Teknologi Sepuluh Nopember (ITS), Kampus ITS Sukolilo, Surabaya 60111, Indonesia \\ ${ }^{2}$ Department of Chemistry, Faculty of Science and Technology, \\ Universitas Airlangga (UNAIR), Kampus C UNAIR, Mulyorejo Surabaya 60115, Indonesia \\ ${ }^{3}$ Centre of Advanced Material and Energy Sciences, \\ University Brunei Darussalam, Jalan Tungku Link, BE 1410, Brunei Darussalam \\ ${ }^{4}$ Ibnu Sina Institute for Scientific and Industrial Research, \\ Universiti Teknologi Malaysia, 81310 UTM Skudai, Johor, Malaysia \\ *Corresponding author: didikp@chem.its.ac.id
}

Received: 25 October 2017; Accepted: 22 January 2019

\begin{abstract}
The activity of zeolite HX acid catalyst synthesized from kaolin was investigated for esterification of acetic acid with benzyl alcohol. Zeolite HX was synthesized using kaolin minerals obtained from Bangka Belitung Sumatra, Indonesia via hydrothermal method and followed by cation exchange treatment. The conversion of acetic acid was driven by the presence of Brønsted acidity with the porosity plays a crucial role in determining product selectivity. The influence of reactants concentration, the effect of reaction time and the amount of catalyst loading were investigated to obtain optimum condition of the reaction. Zeolite HX catalyzed esterification of acetic acid to achieve $58.78 \%$ of conversion with increasing the concentrations of benzyl alcohol enhanced the conversion. The acetic acid esterification follows the Eley-Rideal mechanism with the conversion improved by prolonging the reaction time and increasing the amount of catalyst used in the system.
\end{abstract}

Keywords: zeolite HX, kaolin, esterification, benzyl alcohol, fragrance

\begin{abstract}
Abstrak
Aktiviti mangkin zeolit HX di sintesis daripada kaolin telah dikaji untuk pengesteran asid asetik dan benzil alkohol. Zeolit HX telah di sintesis menggunakan mineral kaolin daripada Bangka Belitung (Sumatra, Indonesia) melalui kaedah hidrotermal dan diikuti rawatan penukaran kation. Aktiviti zeolit ditentukan oleh keasidan intrinsik Brønsted dengan keliangan zeolit HX memainkan peranan penting dalam pemilihan bentuknya. Pengoptimuman terperinci parameter proses seperti nisbah molar, tindak balas masa dan pemangkin ke atas HX juga dijalankan untuk menilai kesan optimum pada aktiviti pemangkin dan pemilihan. Zeolit HX didapati menjadi pemangkin untuk pengesteran dengan penukaran asid asetik sehingga $58.78 \%$ diperolehi dengan peningkatan kepekatan benzil alkohol. Pengesteran asid asetik mengikut mekanisma Eley-Rideal menghasilkan penukaran lebih baik dengan peningkatan dalam masa tindak balas dan jumlah makin yang digunakan di dalam sistem.
\end{abstract}

Kata kunci: zeolit HX, kaolin, pengesteran, benzil alkohol, bau-bauan 


\section{Introduction}

Ester compounds derived from carboxylic acid is an important commodity, which often used in perfumery, plasticizer, solvent and precursor for synthesis of fine chemicals. The synthesis of ester compound involved a direct reaction between carboxylic acid and alcohol, however the approach often limited by equilibrium thus limiting the resulting yield. In order to ensure the completion of the reaction, the presence of acid catalyst and the use of an excess amount of reactants are necessary. Solid acid catalyst has become an ideal choice of catalyst due to better separation between catalyst and the resulting product at the end of the reaction. Zeolite has been extensively studied as acid catalyst for esterification of acetic acid and benzyl alcohol, with HZSM-5 [1], Zeolite HY [2], and H-Beta [3] were among the most investigated catalysts for such reaction. The activity of zeolite was determined based on the intrinsic acidity and the presence of impregnated metal. The porosity of zeolite also contributed to the activity in which the shape and the size of the pores affecting product selectivity. The diffusional limitation caused by the size of the pore often lead to low product selectivity and catalyst deactivation caused by poor accessibility of the reactant to reach the active site of the catalyst and the pore blockage caused by the resulting products that trapped inside the pores [4].

Zeolite NaX from faujasite is composed of sodalite cage with 6-rings (D6R) hexagonal structure with average radius of $1.3942 \mathrm{~nm}$ [5]. The presence of three-dimensional pore structure and the acidity properties of zeolite X have been key aspects that determined its potential as catalyst. In general, zeolite $\mathrm{NaX}$ was prepared using commercial silica and alumina precursors. However, recent work showed that the use of alternative silica and alumina precursor directly obtained from naturally occurring materials such as kaolin produced zeolite with high acidity and porosity. Kaolin is a naturally occurring mineral that abundantly available in Indonesia particularly in south Sumatra, Bangka Belitung and Java Island. Kaolin from Bangka Belitung has low iron and titanium content but rich in silica (54.9 wt.\%) and alumina (36 wt.\%), which is an ideal precursor for synthesizing zeolite NaX.

In this study, the performance of zeolite HX synthesized from kaolin was investigated as acid catalyst in esterification reaction. The activity was also compared to kaolin in order to obtain the effect of porosity and acidity towards the conversion of acetic acid. Optimization of the parameter such as molar ratio of the reactant, the amount of catalyst used, and the reaction time were investigated to enhance the acetic acid conversion and selectivity towards benzyl acetate.

\section{Materials}

\section{Materials and Methods}

Materials used for the synthesis of zeolite HX were kaolin, sodium hydroxide (99 wt.\% NaOH Merck), sodium aluminate (53 wt.\% $\mathrm{NaAlO}_{2}$ Merck), colloidal silica (LUDOX) (30 wt.\% $\mathrm{SiO}_{2}$ and 70 wt.\% $\mathrm{H}_{2} \mathrm{O}$ Merck), ammonium acetate (Merck) for cation exchange. Kaolin was obtained from Bangka Belitung contained 36 wt. $\%$ $\mathrm{Al}_{2} \mathrm{O}_{3}, 54.9$ wt. $\% \mathrm{SiO}_{2}, 3.34$ wt. $\% \mathrm{Fe}_{2} \mathrm{O}_{3}$ and 1.88 wt. $\% \mathrm{~K}_{2} \mathrm{O}$. Pyridine was used as probe molecule for acidity testing to determine the amount of Lewis and Brønsted acid sites of the samples.

\section{Synthesis of zeolite HX as catalyst}

The zeolite $\mathrm{NaX}$ was synthesized by hydrothermal method at $110{ }^{\circ} \mathrm{C}$ for 12 hours according to our previous study [7]. The synthesized gel procedure can be divided into three steps, i.e. (1) the synthesis of seed gel (SG), (2) the synthesis of feedstock gel (FG), and (3) the combination of SG and FG to become overall gel (OV).

The $\mathrm{SG}\left(\mathrm{Al}_{2} \mathrm{O}_{3}: 4 \mathrm{SiO}_{2}\right)$ was prepared by vigorous stirring of $\mathrm{NaOH}$ pellet and demineralized water mixture. Then, the sodium aluminate and colloidal silica were added into $\mathrm{NaOH}$ solution under constant stirring for about 20 minutes until homogeneous mixture were formed. The mixture was then left to age for 24 hours at room temperature. In the second step of the synthesis, the feedstock gel $\left(\mathrm{Al}_{2} \mathrm{O}_{3}: 4.3 \mathrm{SiO}_{2}\right)$ was prepared by mixing colloidal silica and Bangka Belitung kaolin which was used directly without prior treatment. The mixture was dissolved in $\mathrm{NaOH}$ solution. The OV was obtained by combination of the first and second resulting mixture to follow 18 to 1 ratio of FG to SG. The mixture was continuously stirred for another 30 minutes, then left to age for 24 hours at room temperature. The $\mathrm{OV}$ was transferred to polypropylene bottle and heated at $110^{\circ} \mathrm{C}$. The solid produced after hydrothermal treatment was filtered and thoroughly washed with distilled water until the $\mathrm{pH}$ of the supernatant is neutral. The resulting powder was dried and calcined in air at $500{ }^{\circ} \mathrm{C}$ with the heating rate of $2 \% / \mathrm{min}$ for 1 hour. 
The cation exchange was carried out using $1 \mathrm{~N}$ of ammonium acetate solution by mixing with $1 \mathrm{~g}$ of zeolite $\mathrm{NaX}$. The mixture was refluxed at $60{ }^{\circ} \mathrm{C}$ for 3 hours. The solids were filtered and dried at $105^{\circ} \mathrm{C}$ for 24 hours to obtain the $\mathrm{NH}_{4} \mathrm{X}$. The cation exchange process was summarized in equation 1 and 2 . $\mathrm{The} \mathrm{NH}_{4} \mathrm{X}$ was calcined at $550{ }^{\circ} \mathrm{C}$ under air flow for 5 hours to decompose $\mathrm{NH}_{4}$ to $\mathrm{NH}_{3}$, thus forming the $\mathrm{HX}$ catalyst for esterification [9].

$$
\begin{aligned}
& \mathrm{NaX}_{(\mathrm{s})}+\mathrm{CH}_{3} \mathrm{COONH}_{4(\mathrm{l})} \rightarrow \mathrm{NH}_{4} \mathrm{X}_{(\mathrm{s})}+\mathrm{CH}_{3} \mathrm{COONa}_{(\mathrm{l})} \\
& \mathrm{NH}_{4} \mathrm{X}_{(\mathrm{s})} \rightarrow \mathrm{HX}_{(\mathrm{s})}+\mathrm{NH}_{3(\mathrm{~g})}
\end{aligned}
$$

\section{Characterization}

The crystalline phase of zeolite was investigated using X-ray diffraction, XRD. XRD pattern was obtained by Philips $X^{\prime}$ pert XRD instrument with $\mathrm{Cu} \mathrm{K} \alpha$ radiation with a step size of $0.04^{\circ}$ and counting time of $10 \mathrm{~s}$. The data were recorded in the $2 \theta$ range of $5-40^{\circ}$. The morphology of sample was monitored by the micrograph of Scanning Electron Microscopy (SEM) ZEIS EVO MA 10 and coated by Pd/Au. Surface area of the catalyst was measured using nitrogen as adsorbent at $\mathrm{P} / \mathrm{P}_{0}-0.99$ by the BET method. The BJH and SF method were used to determine the size of mesopore and micropore, respectively. TEM HT-7700 micrograph shows the pore types of synthesized material.

Surface acidity was estimated by pyridine FT-IR. About $12 \mathrm{mg}$ of zeolite HX pellet was dehydrated at $400{ }^{\circ} \mathrm{C}$ (heating rate $1^{\circ} \mathrm{C} / \mathrm{min}$ ) for 4 hours with the $\mathrm{N}_{2}$ flow. The temperature was cooled down to room temperature $\left(30^{\circ} \mathrm{C}\right)$ under the flow of $\mathrm{N}_{2}$ and the sample was exposed to pyridine vapor until saturation. The evacuation of excess pyridine was conducted by heating the sample at $150{ }^{\circ} \mathrm{C}$ for 3 hours. The amount of Brønsted and Lewis acid sites was determined by evaluating the amount of remaining adsorbed pyridine detected using infrared spectroscopy at wavenumbers of 1700-1400 $\mathrm{cm}^{-1}$ [9]. The a mount Brønsted (B) and Lewis (L) acid sites were observed from the peaks area of adsorbed pyridine at around 1540 and $1450 \mathrm{~cm}^{-1}$, then followed by calculation of acid sites concentration using B and L extinction coefficients (k) of 1.88 and $1.42 \mathrm{~cm}^{-\mathrm{mmol}^{-1}}$ [10].

\section{Catalytic activities}

The zeolite catalytic activity was performed in a three-neck flask equipped with a water-cooled condenser. This assembly was heated using thermo stated hotplate. The desired amount of catalyst was dried before reacting at 110 ${ }^{\circ} \mathrm{C}$ for 12 hours. Acetic acid was added to benzyl alcohol with a molar ratio of 1:2, 1:4 and 1:6 with each reaction time variation from 0, 60, 240, 360, 480, 600 and 720 minutes. Esterification was carried out over a range of catalyst loading $(2.5,5$ and $10 \mathrm{wt} . \%)$. The supernatant was analyzed by titration with $0.1 \mathrm{~N} \mathrm{KOH}$, using phenolphthalein indicator to get acetic acid conversion [11]. The resulting products were analyzed by gas chromatography- mass spectrometry (GC-MS).

\section{Catalyst characterization}

\section{Results and Discussion}

XRD analysis was used to determine the structure and crystalline phase of the synthesized $\mathrm{NaX}$. The measurement was carried out at diffraction angel between $5-40^{\circ}$ as can be seen in Figure 1(a). The XRD pattern of zeolite X following calcination in air indicates the presence of high crystalline structure with the pattern was identical to the standard of zeolite $X[12]$. The peaks appeared at $2 \theta=6.15 ; 10.02 ; 23.28 ; 26,64 ; 31.95^{\circ}$ showed high diffraction intensity which also identical to the XRD pattern of FAU type as reported by the International Zeolite Association (IZA) [13]. This confirmed that $\mathrm{NaX}$ was successfully formed from kaolin via hydrothermal synthesis. Figure 1(b) showed the SEM images of resulting powder that revealed the morphology of $\mathrm{NaX}$ crystallite as hexagonal structure with average crystallite size of $\sim 1 \mu \mathrm{m}$. The zeolite also consisted of agglomerates to form zeolite cluster. 

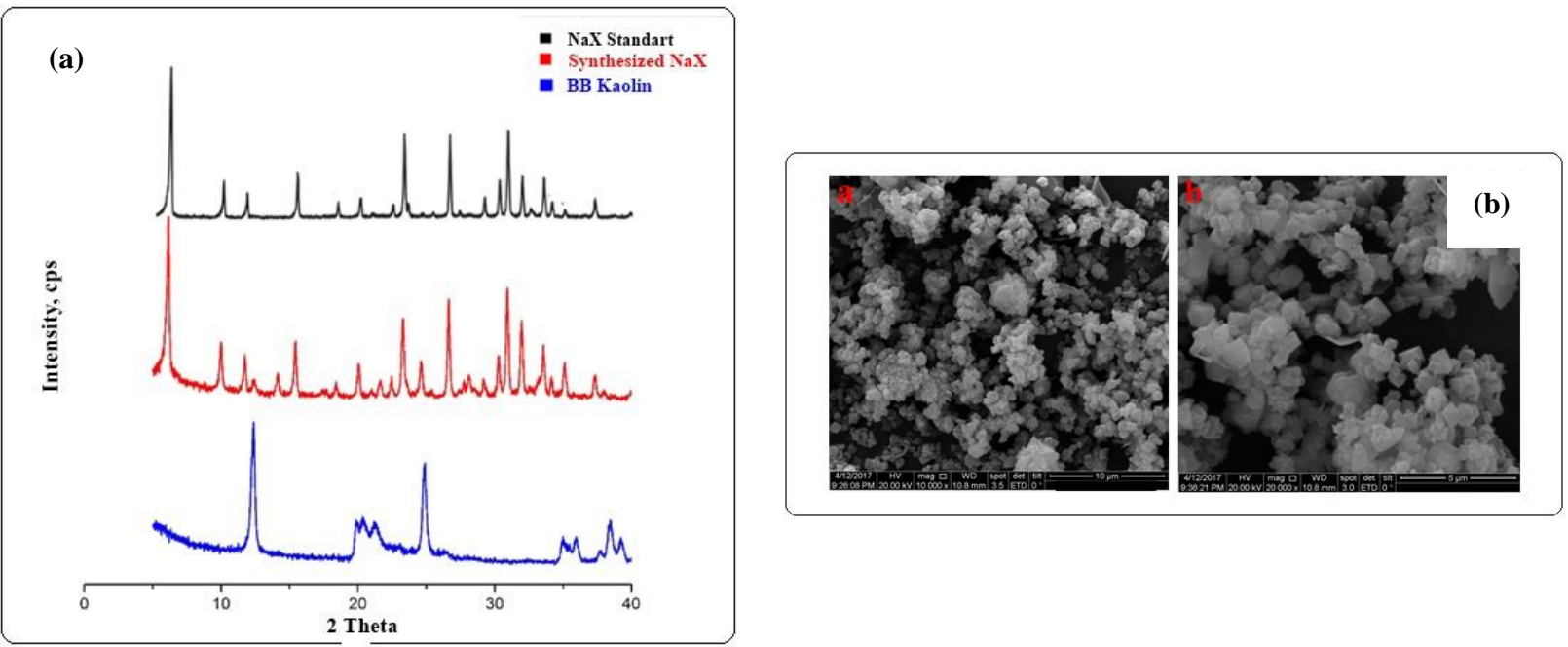

Figure 1. (a) XRD pattern of $\mathrm{NaX}$ standard, synthesized $\mathrm{NaX}$ and kaolin (b) SEM micrograph of $\mathrm{NaX}$ standard (left) and synthesized $\mathrm{NaX}$ (right)

Surface area and pore size distribution of the samples were characterized using nitrogen adsorption-desorption analysis. Specific surface area of kaolin and zeolite HX were analyzed using BET method, with the nitrogen adsorption-desorption profile provides the information of the type of pore of the samples (Figure 2(b)). The isotherm of Zeolite HX showed the adsorption of nitrogen at low relative pressure with hysteresis at $\mathrm{P} / \mathrm{P}_{0}$ of $\sim 0.4$, which were characteristic for isotherm type I and IV. This feature indicated the presence of both microporous and mesoporous structures in the synthesized zeolite. The zeolite HX isotherm showed a high adsorption of nitrogen at relative pressure, $\mathrm{P} / \mathrm{P}_{0}$ within $0-0.3$ which indicates a monolayer formation of adsorbed $\mathrm{N}_{2}$ on the surface. Increasing the relative pressure, $\mathrm{P} / \mathrm{P}_{0}$ the amount of adsorbed nitrogen showed a drastic increment of adsorbed nitrogen volume $\left(\mathrm{P} / \mathrm{P}_{0}>0.4\right)$. The hysteresis loop was also occurred at $\mathrm{P} / \mathrm{P}_{0}$ of 0.4 as shown in Figure 2(a).

Analysis of kaolin showed almost no adsorption of nitrogen at a relative pressure, $\mathrm{P} / \mathrm{P}_{0}$ of $0.01-0.3$ which indicated the kaolin has a type II isotherm. This type II isotherm corresponded to the presence of nonporous structure in the powder. The surface area and pore analysis data calculated from $\mathrm{N}_{2}$ adsorption studies were tabulated in Table 1 .
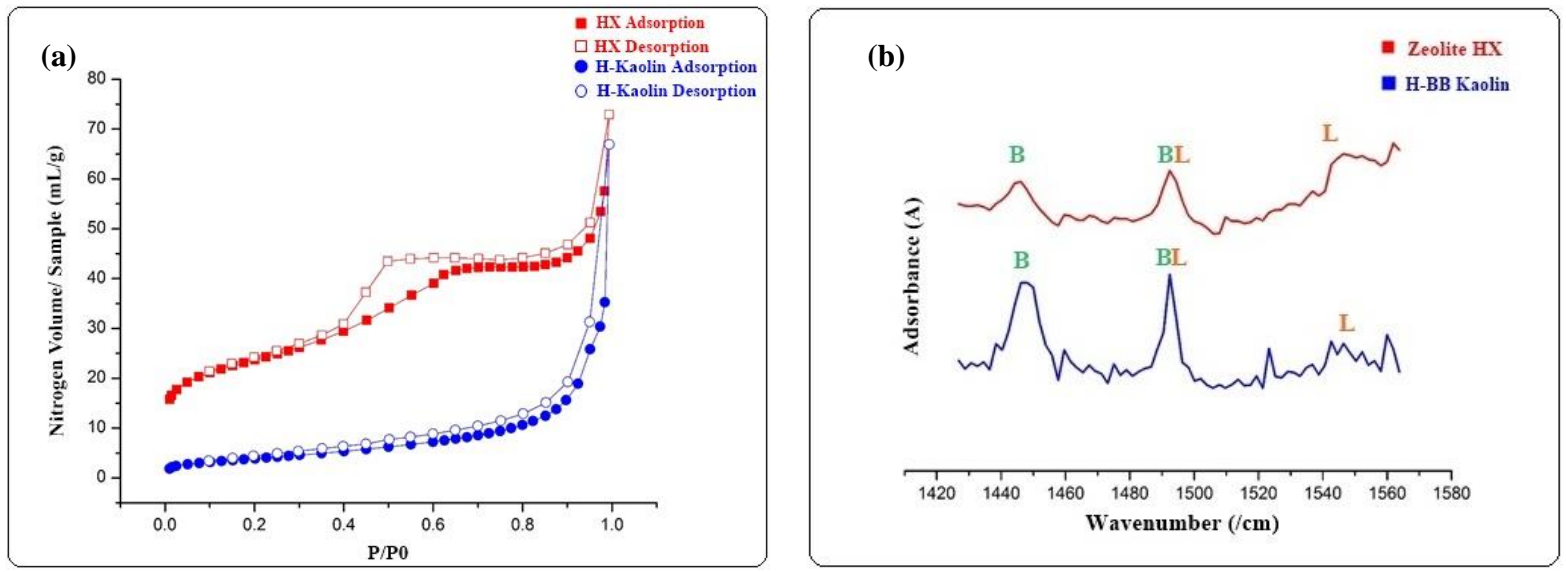

Figure 2. (a) Nitrogen adsorption-desorption isotherm of zeolite HX and kaolin, (b) FTIR spectra of pyridineadsorption on zeolite HX and kaolin 
Table 1. Surface and Pore Analysis of the zeolite HX and kaolin

\begin{tabular}{lcccccccc}
\hline Sample & $\begin{array}{c}\mathbf{S}_{\text {BET }}{ }^{\mathbf{a}} \\
\left(\mathbf{m}^{2} / \mathbf{g}\right)\end{array}$ & $\begin{array}{c}\mathbf{S}_{\text {meso }} \mathbf{d} \\
\left(\mathbf{m}^{2} / \mathbf{g}\right)\end{array}$ & $\begin{array}{c}\mathbf{S}_{\text {mikro }} \\
\left(\mathbf{m}^{\mathbf{2}} / \mathbf{g}\right)\end{array}$ & $\begin{array}{c}\mathbf{V}_{\text {meso }}^{\mathbf{b}} \\
\left(\mathbf{c m}^{\mathbf{3}} \mathbf{g}^{-1}\right)\end{array}$ & $\begin{array}{c}\mathbf{V}_{\text {mikro }}^{\mathbf{b}} \\
\left(\mathbf{c m}^{\mathbf{3}} \mathbf{g}^{-1}\right)\end{array}$ & $\begin{array}{c}\mathbf{V}_{\text {total pori }} \mathbf{c} \\
\left(\mathbf{c m}^{\mathbf{3}} \mathbf{g}^{-1}\right)\end{array}$ & $\begin{array}{c}\mathbf{D}_{\text {meso }} \\
(\mathbf{n m})^{\mathbf{d}}\end{array}$ & $\begin{array}{c}\mathbf{D}_{\text {mikro }} \\
(\mathbf{n m})^{\mathbf{e}}\end{array}$ \\
\hline Kaolin & 14.51 & 16.182 & - & 0.130 & 0.006 & 1.348 & $3.06 ; 3.84$ & $0.35 ; 0.90$ \\
Zeolite HX & 80.24 & 57.169 & 23.071 & 0.096 & 0.027 & 2.256 & 3.41 & 1.47 \\
\hline
\end{tabular}

Figure 3 shows pore size distribution analyzed by BJH and SF method. The pore size analysis of the synthesized zeolite HX indicated the presence of mesopores structure with average diameter of $3.41 \mathrm{~nm}$ (Figure 3(a) and micropores structure with average size of $1.47 \mathrm{~nm}$ (Figure 3(b)). The mesoporous structure was generated from the formation of skeletal framework during the rearrangement and condensation of tetrahedral silica.

Surface acidity of zeolite HX was analyzed using FTIR spectroscopy in the $1700-1400 \mathrm{~cm}^{-1}$ of wavelength region (Figure 2(a)) with using pyridine as probe molecule. The pyridine molecules formed a protonated pyridium $\left(\mathrm{C}_{5} \mathrm{H}_{5} \mathrm{NH}^{+}\right)$ion upon interaction with Brónsted acidity to give adsorption at wavenumber of $1540-1545 \mathrm{~cm}^{-1}$. The interaction between adsorbed pyridine with Lewis acidity formed via coordinated bonding complex between free electron pairs of pyridine molecules with empty orbitals of the Al. This characteristic feature of the coordinated bond occurred at $\sim 1440-1452 \mathrm{~cm}^{-1}$. The band appeared at $1490 \mathrm{~cm}^{-1}$ was assigned to a coordinated site of Brónsted and Lewis acid sites. The amount of Brǿnsted and Lewis acidity of zeolite HX were calculated as 0.1817 and $0.05314 \mathrm{mmol} / \mathrm{g}$, respectively.
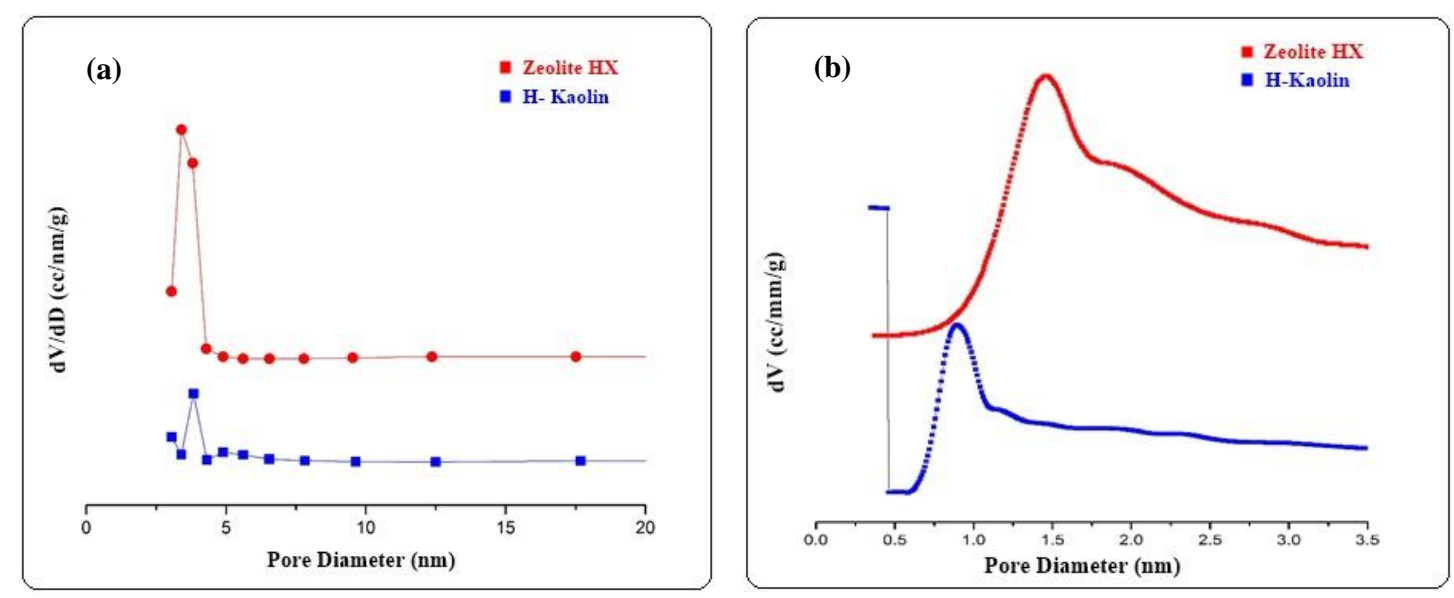

Figure 3. (a) Mesopore distribution (BJH) and (b) micropore distribution (SF) of the samples

Figure 4 shows the TEM images of the synthesized zeolite obtained following calcination in air at $500{ }^{\circ} \mathrm{C}$. The TEM analysis showed a low transmission of electron beam images indicating the zeolite HX was formed of solid packed material without the presence of hollow structure. This indicates that the mesopore structure of the zeolite analyzed by $\mathrm{N}_{2}$ adsorption method was formed due to the intra-cystalline interaction between the particulate zeolite [14]. 


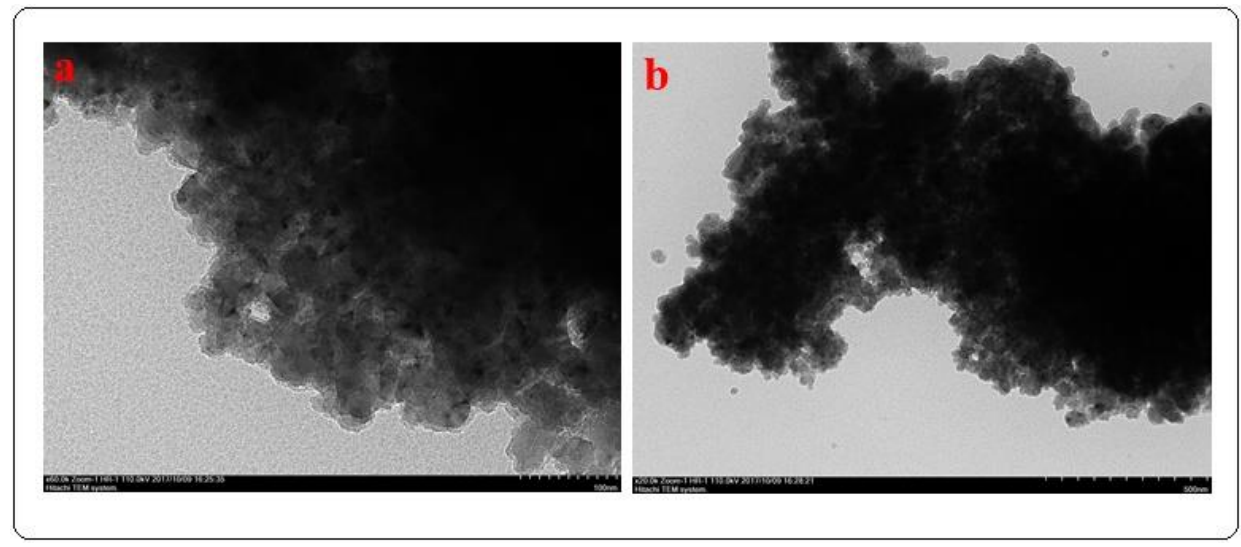

Figure 4. TEM image of zeolite HX

\section{Esterification of acetic acid and benzyl alcohol on zeolite $\mathrm{HX}$ and kaolin}

The activity of the catalyst was evaluated on the esterification of carboxylic acids with alcohol. Acetic acid was chosen as an ideal molecule for esterification reaction on zeolite HX due to the simplicity of the structure to undergo complete esterification without producing coke deposition on the catalysts surface. This is very important to prevent catalyst deactivation, particularly when long reaction was carried out. The catalyst was activated at $105{ }^{\circ} \mathrm{C}$ for 12 hours in air prior to catalytic reaction in order to remove physically adsorbed water molecules and activate the acid sites of the catalyst.

Catalytic performance of zeolite HX and the amount of acid sites were compared to kaolin and the results were illustrated in Figure 5. The esterification reaction was carried out for 4 hours, with molar ratio of acetic acid and benzyl alcohol was kept at 1: 4 ratios (AA: BA) with $2.5 \%$ wt. of catalyst was used in the reaction. Figure 5 shows the conversion of acetic acid for kaolin and zeolite HX. It was found that the catalytic activity of zeolite HX was higher than kaolin to give $\sim 45.41 \%$ of acetic acid conversion. Kaolin surprisingly also showed significant activity with $\sim 20.14 \%$ of acetic acid conversion within 4 hours of reaction. It is apparent that the catalytic activity of zeolite $\mathrm{HX}$ and kaolin were strongly dictated by the amount of acid sites presence on the catalysts surface. The amount of acid sites calculated using the peak area of adsorbed pyridine in infrared spectra showed that H-kaolin has lower Brǿnsted acidity but higher Lewis acidity in comparison to the zeolite HX. This suggests that the esterification of acetic acid with benzyl alcohol favors Brǿnsted acidity which according to the literature, it follows Eley-Rideal mechanism (Figure 9). We also suggest that the pore size of zeolite HX may also contribute to the activity of the catalyst. $\mathrm{N}_{2}$ adsorption analysis revealed the micro-sized diameters of kaolin was smaller than zeolite HX, leading to difficulty of reactant to diffuse and interact with the acid sites within the pore. Furthermore, the mesopore surface area of H-kaolin was lower than zeolite HX, which has detrimental effect on the activity of the catalyst. 


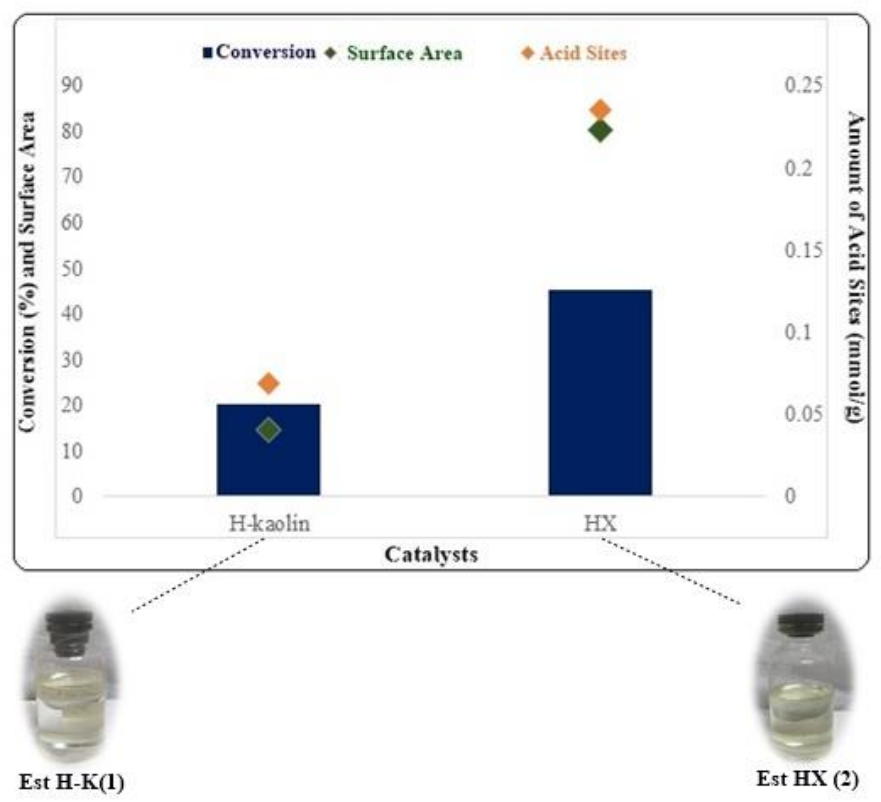

Figure 5. The conversion of acetic acid in esterification with benzyl alcohol on zeolite HX and kaolin as acid catalyst

\section{Effect of acetic acid and benzyl alcohol ratio}

The conversion of acetic acid was investigated by increasing the amount of benzyl alcohol in the reaction. The molar ratio of acetic acid to benzyl alcohol were varied from 1:2, 1:4 to 1: 6 while using zeolite HX as catalyst. The reaction was carried out at $110{ }^{\circ} \mathrm{C}$ for 720 minutes with the product sampling and analysis were measured at 120 minutes interval. The plot of acetic acid conversion with reaction time were shown in Figure 6. The percentage of acetic acid conversion increased at 1:4 acetic acid to benzyl alcohol molar ratio to give $\sim 58.47 \%$ conversion within 720 minutes. This is significantly higher in comparison to the 1:2 acetic acid to benzyl alcohol ratio which gives $\sim 48.03 \%$ of acetic acid conversion. Further increasing the ratio to $1: 6$, the catalytic activity was decreased to give $39.00 \%$ of acetic acid conversion. Although increasing the amount of benzyl alcohol improved catalytic conversion of acetic acid, the presence of excess benzyl alcohol also contributed to deactivation of the catalyst. We attributed this deactivation to the poisoning of acid sites on zeolite HX with benzyl alcohol that consequently inhibited the esterification reaction [15].

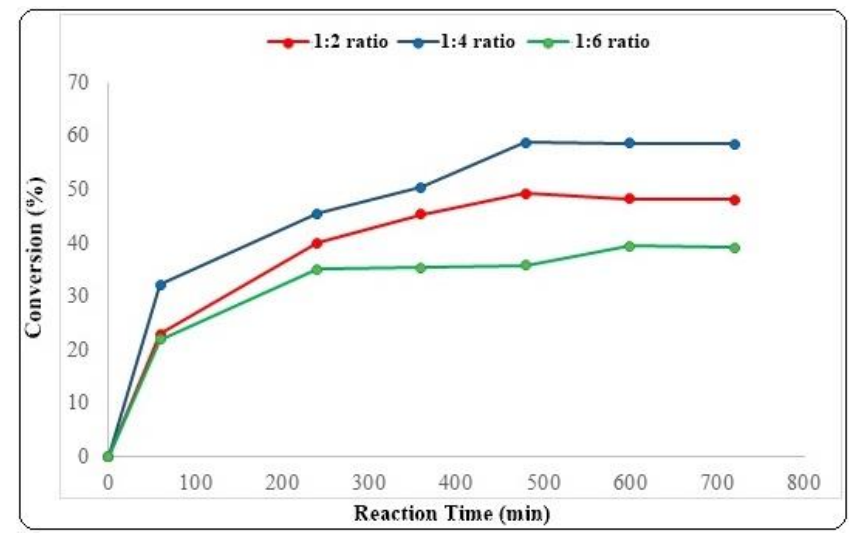

Figure 6. The influence of acetic acid to benzyl alcohol molar ratios on the conversion of acetic acid using zeolite $\mathrm{HX}$ as catalyst 


\section{Effect of reaction time}

Table 2 summarized detail analysis of acetic acid conversion at different reaction time while using zeolite HX as catalyst. The conversion of acetic acid within 60 mins into the reaction showed that the 1:4 ratio was higher than 1:2 and 1:6. It is interesting to see that when the ratio of acetic acid to benzyl alcohol were varied, the reaction reached steady state at different reaction time. At 1:6 molar ratio, the reaction reached steady state at 240 minutes, with extended reaction time showed negligible changes on the conversion. This further consolidate the suggestion that in the presence of excess of benzyl alcohol in the reaction, it is prone to deactivate the active sites of the catalyst, presumably by occupying the acid sites. At 1:4 molar ratio of acetic acid to benzyl alcohol, the reaction achieved steady state at 500 minutes to give maximum acetic acid conversion of $58 \%$.

Table 2. Conversion of acetic acid (\%) with varying molar ratio and reaction time on zeolite HX

\begin{tabular}{lccccccc}
\hline $\begin{array}{l}\text { Molar Ratio } \\
\text { (AA:BA) }\end{array}$ & \multicolumn{6}{c}{ Time (minutes) } \\
\cline { 2 - 8 } & $\mathbf{0}$ & $\mathbf{6 0}$ & $\mathbf{2 4 0}$ & $\mathbf{3 6 0}$ & $\mathbf{4 8 0}$ & $\mathbf{6 0 0}$ & $\mathbf{7 2 0}$ \\
\hline $1: 2$ & 0 & 22.89 & 39.93 & 45.32 & 49.18 & 48.21 & 48.03 \\
$1: 4$ & 0 & 32.15 & 45.41 & 50.31 & 58.78 & 58.58 & 58.47 \\
$1: 6$ & 0 & 21.71 & 35.06 & 35.36 & 35.68 & 39.31 & 39.00 \\
\hline
\end{tabular}

\section{Influence of the amount of acid catalyst}

The influence of the amount of catalyst used during the reaction on the conversion of acetic acid were carried out by increasing the catalyst loading from $2.5 \%, 5 \%$ and $10 \%$ wt. Figure 7 shows the percentage of acetic acid conversion for every reaction. It is clear that the reaction was affected by the amount of acid catalyst with the conversion increased from $45.41 \%$ to $48.04 \%$.

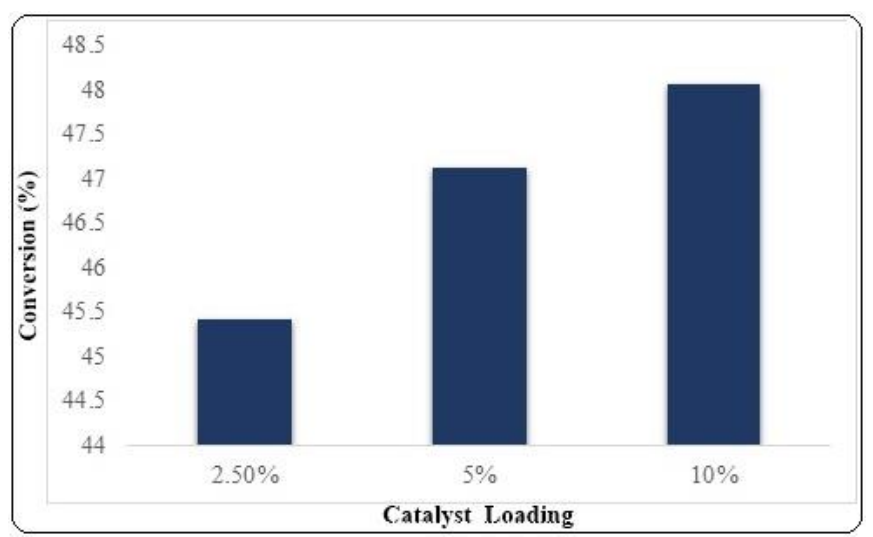

Figure 7. The influence of catalyst loading on acetic acid conversion (\%)

The product of esterification reaction over zeolite HX was analyzed using GC-MS as shown in Figure 8. Only one product was detected, and it was identified as benzyl acetate. This indicate the selectivity of the reaction towards esterification product, benzyl acetate was $100 \%$. The presence of benzyl alcohol (peak 1) and benzyl acetate (peak 2) were shown at retention time of 9.74 and 10.47 minutes (Figure 8). The catalytic mechanisms of benzyl acetate formation were proposed in Figure 9. We suggest that the reaction followed the Eley-Riedel mechanism previously proposed by Kirumaki et al. [5]. The reaction involved several mechanistic steps i.e. the adsorption of acetic acid on Brónsted acid sites that increased the electrophilicity of the carbon carbonyl; the nucleophile on benzyl alcohol interacted with the carbonyl to form an oxonium ion; proton transfer lead to water removal, and finally deprotonation to form the benzyl acetate [16]. 


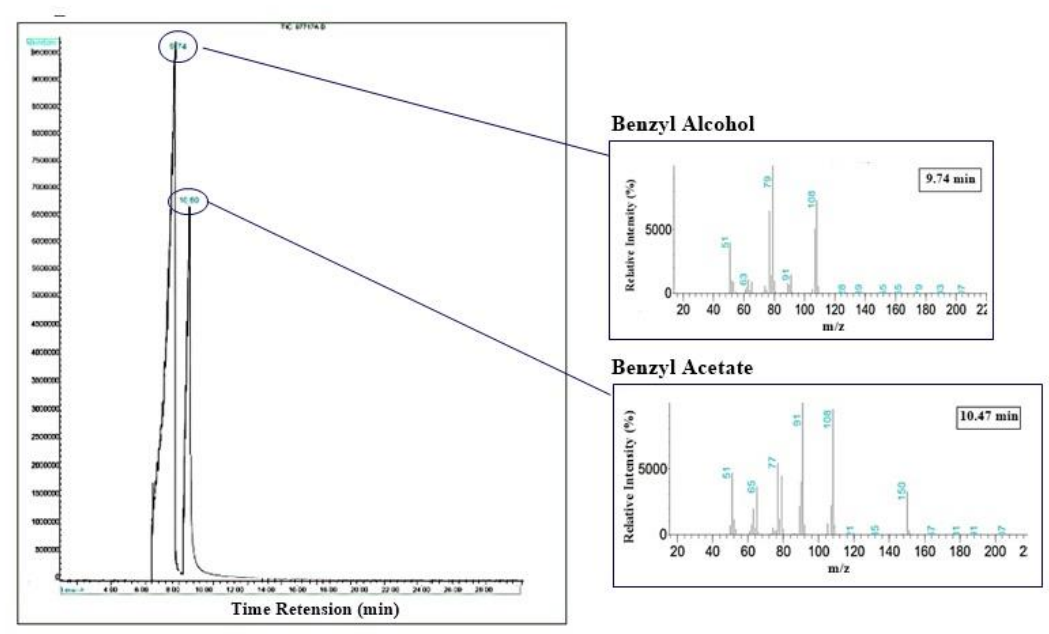

Figure 8. The GC-MS of esterification product

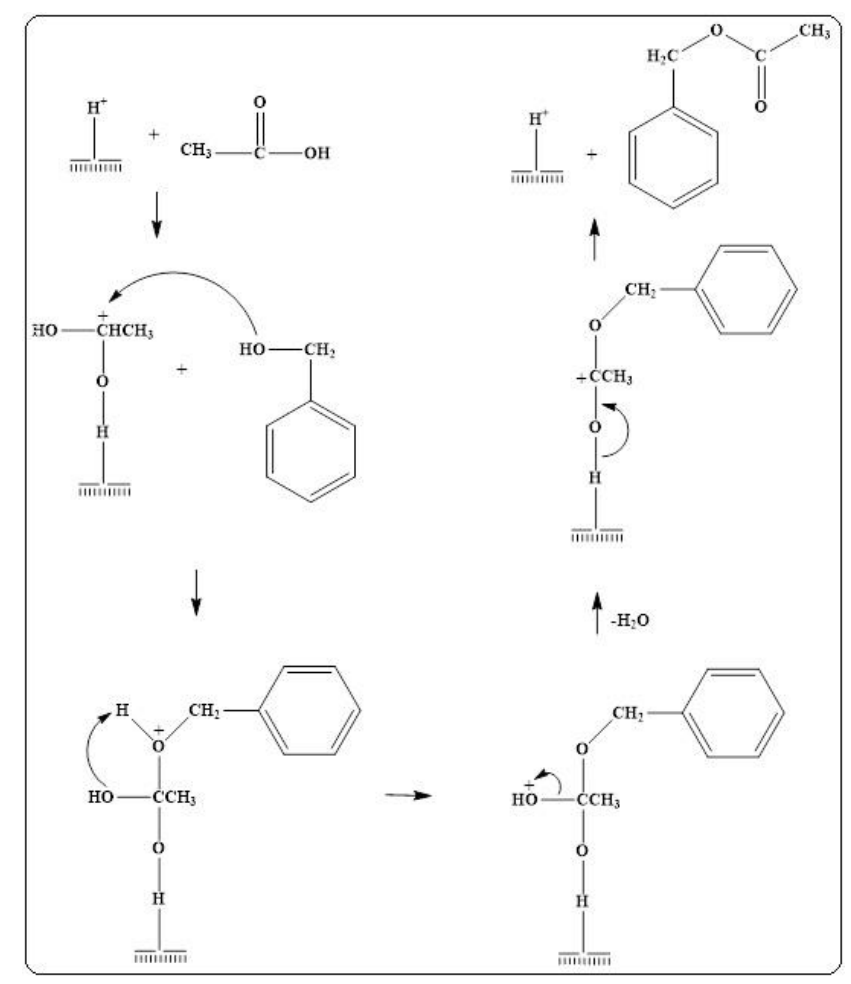

Figure 9. Proposed mechanism for esterification of acetic acid and benzyl alcohol

\section{Conclusion}

The activity of the synthesized zeolite HX catalyst from kaolin was investigated in esterification reaction of acetic acid with benzyl alcohol. The high activity of zeolite HX catalyst in the esterification reaction of acetic acid was due to the presence of Brónsted acidity $(0.1817 \mathrm{mmol} / \mathrm{gram})$ with high surface area $\left(80.24 \mathrm{~m}^{2} / \mathrm{gram}\right)$ and mesopore structure $(3.41 \mathrm{~nm})$. Optimization studies of the reaction revealed that varying the molar ratios of acetic acid to 
benzyl alcohol increased the conversion to $58.78 \%$ with $100 \%$ selectivity towards benzyl acetate. The conversion of acetic acid was also improved when the reaction time was increased to 720 minutes. The amount of catalyst used during the reaction was also affected the catalytic conversion of benzyl alcohol to benzyl acetate.

\section{Acknowledgement}

Authors would like to acknowledge the Ministry of Research and Higher Education, Indonesia, under "PBK" research grant 2017-2019.

\section{References}

1. Kirumakki S. R., Nagaraju N. and Narayanan S. (2003). Kinetics of esterification of aromatic carboxylic acid over zeolites H $\beta$ aand HZSM5 using dimethyl carbonate. Applied Catalysis A: General, 248: 161-167.

2. Kirumakki S. R., Vijayashree, S. and Nagaraju, N. (2001). Catalytic esterification of benzyl alcohol with acetic acid by zeolites and their modified forms. Indian Journal of Chemical Technology, 8: 362-367.

3. Kirumakki S. R., Nagaraju N. and Chary K. V. R. (2006). Esterification of alcohols with acetic acid over zeolites H $\beta$, HY and HZSM5. Applied Catalysis A: General, 299: 185-192.

4. Gokulakrishnan, N., Pandurangan, A. and Sinha, P. K. (2007). Esterification of acetic acid with propanol isomers under autogeneous pressure: A catalytic study of Al-MCM-41 molecular sieves. Journal of Molecular Catalysis A: Chemical, 263: 55-61.

5. Kirumakki S. R., Nagaraju N. and Narayanan S. (2004). A comparative esterification of benzyl alcohol with acetic acid over zeolites H $\beta$, HY and HZSM5. Applied Catalysis A: General, 273: 1-9.

6. Mozgawa, W., Krol M. dan Barczyk. (2011). FT-IR of zeolites from different structural groups.Chemik, 65(7): 667-674.

7. Iftitahiyah. V. N. (2016). Synthesis of zeolite NaX from Bangka Belitung Kaolin as renewable source and its characterization. Thesis. Institut Teknologi Sepiluh November, Indonesia (ITS)

8. Jermy, B. R. dan Pandurangan, A. (2005). Catalytic application of Al-MCM-41 in the esterification of acetic acid with various alcohols. Applied Catalysis A: General, 288(1-2): 25-33.

9. Hartati, Prasetyoko, D., Santoso, M., Bahruji, H. and Triwahyono, S. (2014). Highly active aluminosilicates with a hierarchical porous structure for acetalization of 3,4- dimethoxybenzaldehyde. Jurnal Teknologi (Sciences \& Engineering) 69(5): 25-30.

10. Emeis, C. A. (1993). Determination of integrated molar extinction coefficients for infrared absorption bands of pyridine adsorbed on solid acid catalysts. Journal of Catalysis, 141: 347-354.

11. Kusumaningtyas, D., Prasetyoko, D., Suprapto., Sugeng, T., Jalil A. A. and Rosyidah, A. (2017). Esterification of benzyl alcohol with acetic acid over H-ZSM-5 mesoporous. Bulletin of Chemical Reaction Engineering and Catalysis, 12(2): 243-250.

12. Purnomo, C. W., Salim, C. dan Hinode, H. (2012). Synthesis of pure $\mathrm{Na}-\mathrm{X}$ and Na-A zeolite from bagasse fly ash. Microporous and Mesoporous Materials, 162: 6-13.

13. Khoshbin, R. and Karimzadeh, R. (2017). Synthesis of mesoporous ZSM-5 from rice husk ash with ultrasound assisted alkali-treatment method used in catalytic cracking of light naphtha. Advanced Powder Technology, 28(8): 1888-1897.

14. Schmidt, F., Lohe, M. R., Buchner, B., Giordanino, F., Bonino, F. and Kaskel, S. (2013). Improved catalytic performance of hierarchical ZSM-5 synthesized by desilication with surfactants. Micropore Mesopore Materials. 165: 148-157.

15. Induri, S., Sengupta, S., dan Basu, J. K. (2010). A kinetic approach to the esterification of maleic anhydride with methanol on H-Y zeolite. Journal of Industrial and Engineering Chemistry, 16(3): 467-73.

16. Nandiwale K. Y., Galande N. D., Raut S. A. and Bokade V. V. (2015). Benzylation of acetic acid to benzyl acetate over highly active and reusable micro/meso HZSM5. Chemical Engineering Research and Design, 93: 584-590. 